\title{
Comparison of the Patient Groups with and Without Dissociative Disorder Comorbidity among the Inpatients with Bipolar Disorder
}

\section{Yatarak Tedavi Gören Bipolar Bozukluk Hastalarında Dissosiyatif Bozukluk Eştanısı Olan ve Olmayan Hasta Gruplarının Karşılaştırılması}

\author{
Bahadır Bakım ${ }^{1}$, Elif Baran ${ }^{2}$, Mehmet Diyaddin Güleken ${ }^{3}$, Onur Tankaya ${ }^{4}$, Sinan Yayla ${ }^{5}$, Abdullah Akpınar $^{6}$, Hakan \\ Serdar Sengul ${ }^{7}$, Hülya Ertekin ${ }^{8}$, Ömer Akil Özer ${ }^{2}$, Kayıhan Ŏguz Karamustafalıŏglu ${ }^{9}$
}

${ }^{1}$ Ruh Sağlığı ve Hastalıkları Ana Bilim Dalı, Tıp Fakültesi, İstanbul Yeni Yüzyıl Üniversitesi, İstanbul, Türkiye

${ }^{2}$ Psikiyatri Kliniği, Şişli Hamidiye Etfal Eğitim ve Araştırma Hastanesi, İstanbul, Türkiye

${ }^{3}$ Gazi Yaşargil Eğitim ve Araștırma Hastanesi, Diyarbakır, Türkiye

${ }^{4}$ Ruh Sağlığı Hastalıkları Hastanesi, Samsun, Türkiye

${ }^{5}$ Çorlu Devlet Hastanesi, Tekirdağ, Türkiye

${ }^{6}$ Ruh Sağlığı ve Hastalıkları Ana Bilim Dalı, Tıp Fakültesi, Süleyman Demirel Üniversitesi, Isparta, Türkiye

${ }^{7}$ Taksim İlk Yardım Hastanesi, İstanbul, Türkiye

${ }^{8}$ Ruh Sağlığı ve Hastalıkları Ana Bilim Dalı, Tıp Fakültesi, Çanakkale, Türkiye

${ }^{9}$ Üsküdar Üniversitesi, İstanbul, Türkiye

\begin{abstract}
Introduction: This study aims to compare sociodemographic characteristics of the patients with bipolar disorder (BD) with and without comorbid dissociative disorder (DD) and to investigate the eventual effect of the comorbidity on the treatment.

Methods: We enrolled a total of 149 patients diagnosed with BD and treated as inpatients consecutively in Şişli Etfal Hospital, Psychiatry Clinic between 2010 and 2011. For the patients who were diagnosed with DD using SCID-D and with BD using SCID-I, sociodemographic characteristics, YMRS, HAM-D, BPRS, DES scores and duration and number of hospital stays were evaluated.

Results: 23 patients (15.4\%) had dissociative disorder not otherwise specified (DD-NOS), 4 patients (2.6\%) had dissociative identity disorder (DID) and 1 patient $(0.6 \%)$ had dissociative amnesia. BD patients with comorbid DD were found to be predominantly female $(p=0.015)$ and younger $(p=0.002)$ and to have significantly higher DES scores than BD patients without DD ( $p<0.001)$. The total score of DES was correlated with duration hospital stay $(\mathrm{p}=0.001$, Spearman $\mathrm{r}=0.336)$ in the total sample. Total HAM-D score at the time of admission was significantly higher in the comorbidity group ( $\mathrm{p}=0.027)$, and suicide item was found to be significantly higher both at admission and at discharge ( $\mathrm{p}<0.001$ and $\mathrm{p}=0.035)$. Among BPRS scores at admission, hallucinatory behavior item was found to be higher in the comorbidity group $(\mathrm{p}=0.019)$. Among YMRS scores both at admission and at discharge, velocity and amount of speech item $(\mathrm{p}=0.027)$ and insight item at admission $(\mathrm{p}=0.006)$ was found to be significantly higher in the pure bipolar group ( $\mathrm{p}=0.018)$. Conclusion: In patients with BD, DD comorbidity should be investigated. The BD patients with DD comorbidity tend to be female and younger, and show higher depression scores, leading to a prolonged hospital stay. In the presence of dissociation comorbidity, attempts and number of suicides and hallucinatory behaviors seem to be increased.
\end{abstract}

Keywords: bipolar disorder, dissociative disorder, comorbidity

\section{ÖZET}

Giriș: Bu çalışmada dissosiyatif bozukluk (DB) eștanısı olan ve olmayan bipolar bozukluk (BB) hastalarının sosyodemografik karakteristiklerinin karşılaştırılması ve eştanı varlığının tedaviye etkisinin değerlendirilmesi amaçlanmıştır.

Yöntem: BB tanısı ile Şişli Etfal Hastanesi Psikiyatri Kliniği'nde 2010-2011 yılları arasında yatışı yapılan ardışık 149 hasta çalışmaya alınmıştır. Hastalara SCID-D uygulanarak DB tanısı, SCID-I ile BB tanısı konmuş, sosyodemografik karakteristikleri, YMDÖ, HAM-D, KPDÖ, DYÖ puanları ve hastanede yatış süre ve sayıları incelenmiştir.

Bulgular: 23 hastada $(\% 15,4)$ başka türlü adlandırılamayan dissosiyatif bozukluk, 4 hastada $(\% 2,6)$ dissosiyatif kimlik bozukluğu, 1 hastada $(\% 0,6)$ dissosiyatif amnezi tespit edildi. DB eştanısı olan BB hastalarının daha genç ve daha fazla oranda kadın olduğu belirlendi (sırasıyla $\mathrm{p}=0,002, \mathrm{p}=0,015$ ). DB eştanılı BB hastalarının DYÖ toplam puanının BB hastaların daha yüksek olduğu tespit edildi $(p<0,001)$. Tüm örneklemde DYÖ toplam puanı ile hastanede kalış süresi arasında korelasyon bulunmuştur ( $\mathrm{p}=0,001$, Spearman $r=0.336)$. Başvuru sırasında toplam HDÖ puanı eştanılı grupta anlamlı olarak daha yüksek ( $p=0,027)$, intihar maddesi hem başvuru hem taburculukta anlamlı olarak yüksek bulunmuştur $(\mathrm{p}<0,001$ ve $\mathrm{p}=0,035)$. Başvuru esnasında KPDÖ puanlarından, halüsinatuar davranış maddesi eştanılı grupta yüksek bulunmuştur $(\mathrm{p}=0,019)$. YMDÖ puanlarından konuşma hız ve miktarı hem başvuru hem taburculukta (sırasıyla $\mathrm{p}=0,027, \mathrm{p}=0,006$ ), içgörü maddesi ise başvuru esnasında eştanının olmadı̆̆ bipolar hasta grubunda yüksek bulunmuştur $(\mathrm{p}=0,018)$.

Sonuç: BB hastalarında DB eştanısı sorgulanmalıdır. DB eştanılı hastaların daha çok kadın cinsiyette ve daha genç yaşta olduğu, daha fazla depresyon puanlarına sahip olduğu; daha uzun süreli hastanede kalış süresine sahip olduğu bulunmuştur. Dissosiyasyon eştanısı varlığında, intihar girişim sayısı ve halüsinatuar davranışlarda artış görülebilir.

Anahtar kelimeler: Bipolar bozukluk, disosiyatif bozukluk, komorbidite

Submission / Başvuru: April / Nisan 20, $2016 \quad$ Acceptance / Kabul: July / Temmuz 13, 2016

Correspondence / Yazışma: İstanbul Yeni Yüzyıl Üniversitesi Tıp Fakültesi, İstanbul, Türkiye

E-mail: bbakim@yahoo.com

Cite / Atıf: Bakım B, Baran E, Güleken MD, Tankaya O, Yayla S, Akpınar A, Sengul HS, Ertekin H, Özer ÖA, Karamustafalığlu KO. Comparison of the patient groups with and without dissociative disorder comorbidity among the inpatients with bipolar disorder. Fam Pract Palliat Care. 2016;1(2):35-42 


\section{INTRODUCTION}

The prevalence of bipolar disorder (BD) was reported to be $0.4-1.1 \%$ (1). However, the lifetime prevalence estimates for bipolar spectrum disorders are now placed at least $5 \%$ of the general population (2), with some authors yielding even higher estimates (3). Psychiatric comorbidities are especially common among patients with bipolar disorder (4). While the incidence of lifetime comorbidity in bipolar samples is commonly reported to be above $50 \%$, some authors report the incidence rates as high as $70 \%(5)$.

Dissociative disorders were found in approximately 5-10\% of the general population $(6,7)$. Dissociative psychopathology has been linked to traumatic experiences $(8,9)$. Childhood trauma has been associated with the development of most psychiatric disorders, including mood and anxiety disorders, eating disorders, personality disorders, dissociative disorders, substance dependence and psychosis (10).

Patients with dissociative disorders frequently have concurrent Axis I disorders $(11,12)$. Although comorbidities are common in dissociative disorders (DD), cases in which bipolar Disorder (BD) are comorbid with DD are generally overlooked because dissociative symptoms are obscure and they impair the individual's self-perception and self-report. Comorbidity between a wide range of dissociative disorders and bipolar disorder has not been investigated yet. The primary goal of the present study was to determine the differences of comorbid dissociative disorder and bipolar disorder from bipolar disorder alone.

\section{METHODS}

\section{Sample}

One hundred and forty nine consecutive patients diagnosed with bipolar disorder in the psychiatric inpatient clinic of Sisli Etfal Teaching and Research Hospital between January 2010 and January 2011 were enrolled in this study. Inclusion criteria were fulfillment of the DSM-IV criteria for bipolar disorder and being aged between 18 and 65 years-old. Exclusion criteria were mental retardation, schizophrenia/psychotic disorder, alcohol/substance addiction disorders, dementia/other cognitive disorders, personality traits due to neurological diseases such as epilepsy, migraines, multiple sclerosis and Parkinson's disease, the presence of a systemic disease that causes cognitive impairment or the presence of physical illness affecting vision, auditory and/or motor capabilities.

\section{Assessment tools}

Sociodemographic form: This questionnaire gathered data on the age, gender, marital status, education status, the age of onset of bipolar disorder, number of hospitalizations, previous suicide attempts and mean hospital stay of patients.

Assessment of bipolar disorder and symptom severity:

Patients were evaluated using Structured Clinical Interview for DSM-IV Axis I Disorders (SCID-I) developed by First and colleagues (13). The validity and reliability studies have been conducted for Turkey (14).

The Hamilton Rating Scale for Depression (HDRS) was developed by Hamilton and the original scale has 17 items measuring the severity of depression (15). The reliability and validity of the Turkish form has been examined (16).

The Young Mania Rating Scale (YMRS): Young et al. (17) developed a mania rating scale consisted of eleven items and five grades of severity specific to each item. The reliability and validity of the Turkish form has been examined (18).

The Brief Psychotic Rating Scale: The scale was developed by Overall and Gorham (19) and was translated to Turkish by Soykan (20).

Assessment of dissociative disorders and dissociative symptom severity:

Dissociative Event Scale (DES): It has been demonstrated that the scale differentiates patients with a chronic dissociative disorder and those with other psychiatric disorders (21). The Turkish version of the scale has a reliability and validity (22).

The Structured Clinical Interview for DSM-IV Dissociative Disorders (SCID-D) (23) is a semistructured diagnostic interview for the assessment of dissociative disorders according to the DSM-IV criteria. It contains five symptom areas, including amnesia, depersonalization, derealization, identity confusion, and identity alteration. The interview was widely tested in evaluation studies and provided good to excellent reliability and validity (24).

\section{Statistical analysis}

To examine group differences on demographic and clinical data two-tailed independent samples t-tests or Mann Whitney $\mathrm{U}$ tests were performed, depending on whether data were normally distributed (as assessed using the ShapiroWilk test of normality). All data were analyzed in Statistical Package for Social Sciences (SPSS) for Windows 14.0 using 2-tailed tests and $\alpha=0.05$. Possible differences in sociodemographic characteristics were investigated using chi-square tests. Intragroup comparisons were performed using Wilcoxon test. Correlations between duration of hospital stay and DES total scores were evaluated by Spearman's rho.

\section{RESULTS}

One hundred and forty nine patients with bipolar disorder were enrolled in the study. 121 patients $(81 \%)$ had bipolar disorder without dissociative disorder and 28 patients (18.7\%) had bipolar disorder with dissociative disorder. Twenty-three patients $(15.4 \%)$ had dissociative disorder - not otherwise specified (DD-NOS), four had dissociative identity disorders (DID) $(2.6 \%)$, and one had dissociative amnesia (DA) $(0.6 \%)$.

The mean age of pure bipolar group was $37.01 \pm 12.74$ years, and the mean age of bipolar group with dissociative disorder comorbidity was $30.64 \pm 8.69$ years. Pure bipolar group were significantly older than comorbid group $(\mathrm{t}=3.171$; $\mathrm{p}=0.002)$. There were 74 females $(61.5 \%)$ and 47 males $(38.5 \%)$ in the pure bipolar group and 24 females $(85.7 \%)$ and 4 males $(14.3 \%)$ in the comorbidity group. There were a greater number of male patients in the pure bipolar group compared to comorbidity group $\left(\mathrm{x}^{2}=5.963 \mathrm{p}=0.015\right)$. No significant difference was found between the groups in terms of the duration of education, marital status and general medical status. The groups were found to be similar in terms of the number of hospitalizations and the hospital stay. 
COMPARISON OF CLINICAL CHARACTERISTICS (DES SCORE, YMRS, BPRS, HAMILTON SCALE SCORE)

Total DES scores were found to be $22.79 \pm 18.64$ in the pure bipolar group and $44.60 \pm 21.23$ in the comorbidity group and this difference was significant $(\mathrm{z}=-4.24, \mathrm{p}<0.001)$. A significant correlation was detected between total DES score and hospital stay and this correlation was found to be positive (Spearman's rs=0.336; $\mathrm{p}=0.001$ ).

When two groups were compared in terms of the total scores of HAM-D, YMRS ve BPRS at admission and at discharge, only HAM-D scores at admission was found to be increased significantly in the comorbidity group compared to pure bipolar group $(\mathrm{z}=-2.212, \mathrm{p}=0.027)$ (Table 1). HAM-D scores for 3rd item (suicide) and 17th item (insight about the condition) at the time of admission (Table 1) and at the time of discharge (Table 2) were significantly higher in the comorbidity group compared to pure bipolar disorder group $(\mathrm{z}=4.08, \mathrm{p}<0.001 ; \mathrm{z}=2.11, \mathrm{p}=0.035 ; \mathrm{z}=2.49, \mathrm{p}=0.013 ; \mathrm{z}=2.63$, $\mathrm{p}=0.009$, respectively).

In the pure bipolar group, there was a significant difference between HAM-D scores at admission and at discharge, except for 17 th item. In the comorbidity group, a significant difference was detected between the scores at admission and at discharge, except for 9th (agitation), 11th (somatic anxiety), 15 (hypochondriasis), 16th (weight loss) and 17th (insight about the condition) items (Table 1 and 2).
Table 1. HAM-D item scores of patient groups at admission

\begin{tabular}{lcccr}
\hline & Pure BD & Comorbidity & \multicolumn{2}{c}{ Mann-Whitney } \\
& ne28 & Group $\mathbf{n = 2 8}$ & \multicolumn{2}{c}{ U } \\
& SD & Mean \pm SD & Z & \multicolumn{1}{c}{ p } \\
\hline HAMD1 & $1.6 \pm 1.5$ & $2.1 \pm 1.5$ & 1.59 & 0.113 \\
HAMD2 & $1.0 \pm 1.1$ & $1.4 \pm 1.0$ & 1.89 & 0.059 \\
HAMD3 & $1.2 \pm 1.5$ & $2.5 \pm 1.4$ & 4.08 & $<\mathbf{0 . 0 0 1}$ \\
HAMD4 & $1.2 \pm 1.4$ & $1.4 \pm 0.7$ & 1.33 & 0.184 \\
HAMD5 & $0.9 \pm 0.8$ & $1.0 \pm 0.7$ & 0.50 & 0.615 \\
HAMD6 & $0.7 \pm 0.8$ & $0.7 \pm 0.8$ & 0.52 & 0.604 \\
HAMD7 & $1.8 \pm 1.3$ & $2.1 \pm 1.1$ & 0.97 & 0.332 \\
HAMD8 & $0.6 \pm 0.8$ & $0.6 \pm 0.6$ & 0.03 & 0.978 \\
HAMD9 & $0.6 \pm 0.7$ & $0.6 \pm 0.7$ & 0.89 & 0.374 \\
HAMD10 & $1.5 \pm 1.4$ & $1.9 \pm 1.1$ & 1.45 & 0.148 \\
HAMD11 & $1.2 \pm 1.2$ & $1.5 \pm 1.2$ & 1.36 & 0.174 \\
HAMD12 & $0.4 \pm 0.6$ & $0.5 \pm 0.6$ & 0.67 & 0.504 \\
HAMD13 & $0.6 \pm 0.7$ & $0.8 \pm 0.8$ & 1.46 & 0.145 \\
HAMD14 & $0.8 \pm 0.9$ & $1.1 \pm 0.9$ & 1.72 & 0.085 \\
HAMD15 & $0.4 \pm 0.9$ & $0.4 \pm 0.9$ & 0.03 & 0.978 \\
HAMD16 & $0.5 \pm 0.8$ & $0.3 \pm 0.7$ & 1.57 & 0.117 \\
HAMD17 & $0.4 \pm 0.7$ & $0.1 \pm 0.4$ & 2.49 & 0.013 \\
\hline
\end{tabular}

HAM-D: Hamilton Rating Scale for Depression. BD: Bipolar Disorder * $\mathrm{p}<0.05$ SD: Standard Deviation

Table 2. HAM-D item scores of patient groups at discharge

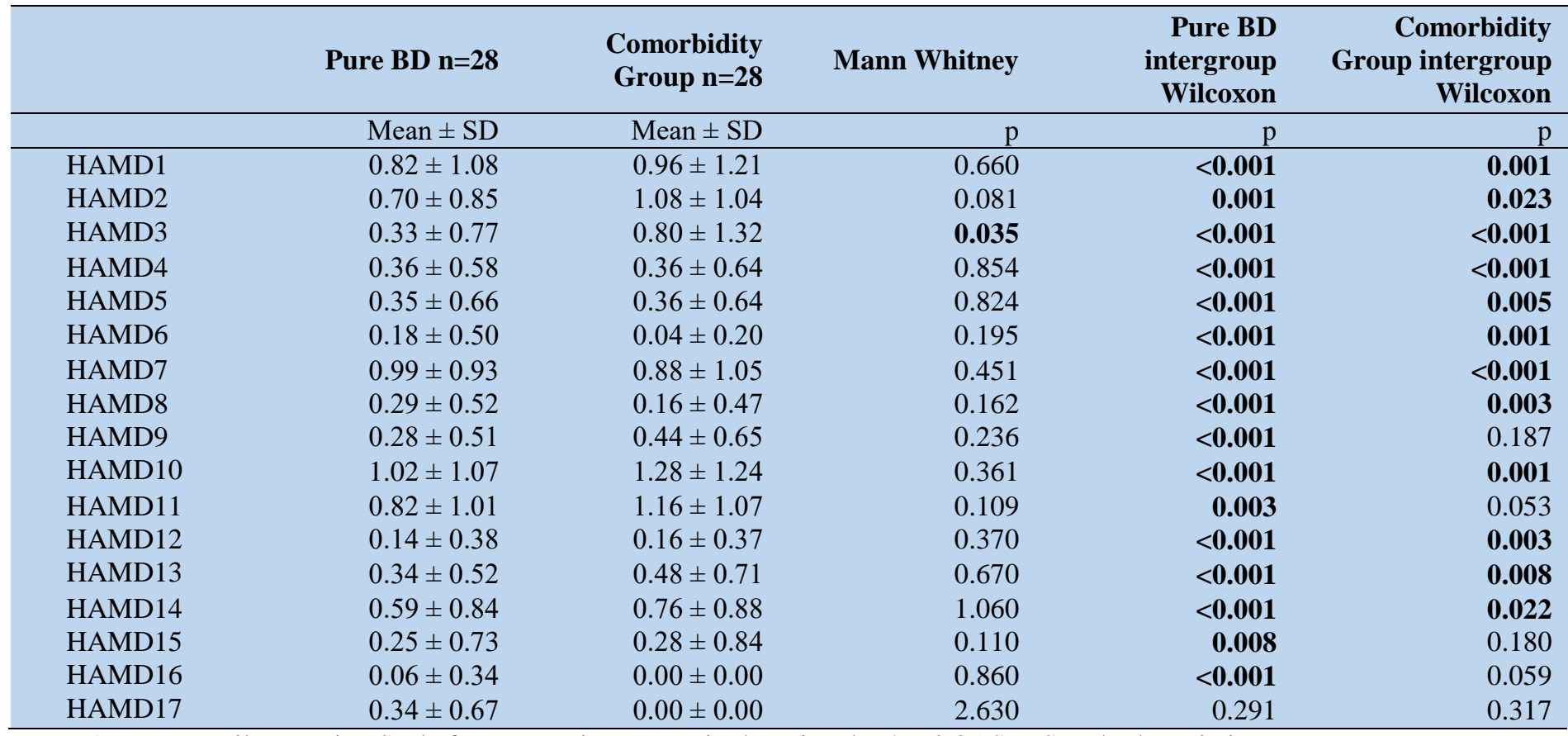

HAM-D: Hamilton Rating Scale for Depression. BD: Bipolar Disorder *p<0.05 SD: Standard Deviation

Among BPRS scores at admission, 12th item (hallucinatory behavior) was found to be $1.27 \pm 2.10$ in the pure bipolar group and $2.33 \pm 2.37$ in the comorbidity group, representing a significant difference $(\mathrm{z}=2.34, \mathrm{p}=0.019)$ (Table 3 ). Among the BPRS scores at the time of discharge, 8th item (grandiosity) was found to be $0.96 \pm 1.55$ in the pure bipolar group and $0.27 \pm 0.72$ in the comorbidity group, representing a significant difference $(\mathrm{z}=2.33, \mathrm{p}=0.020)$ (Table 4$)$. In the pure bipolar group, a significant difference was found between BPRS scores at admission and at discharge, except for 1st (somatic occupations) and 18th items (disorientation). In the comorbidity group, a significant difference was found between BPRS scores at admission and at discharge, except for 7th (mannerism and posture) and 18th items (disorientation) (Table 3 and 4). 
Table 3. BPRS item scores of patient groups at admission

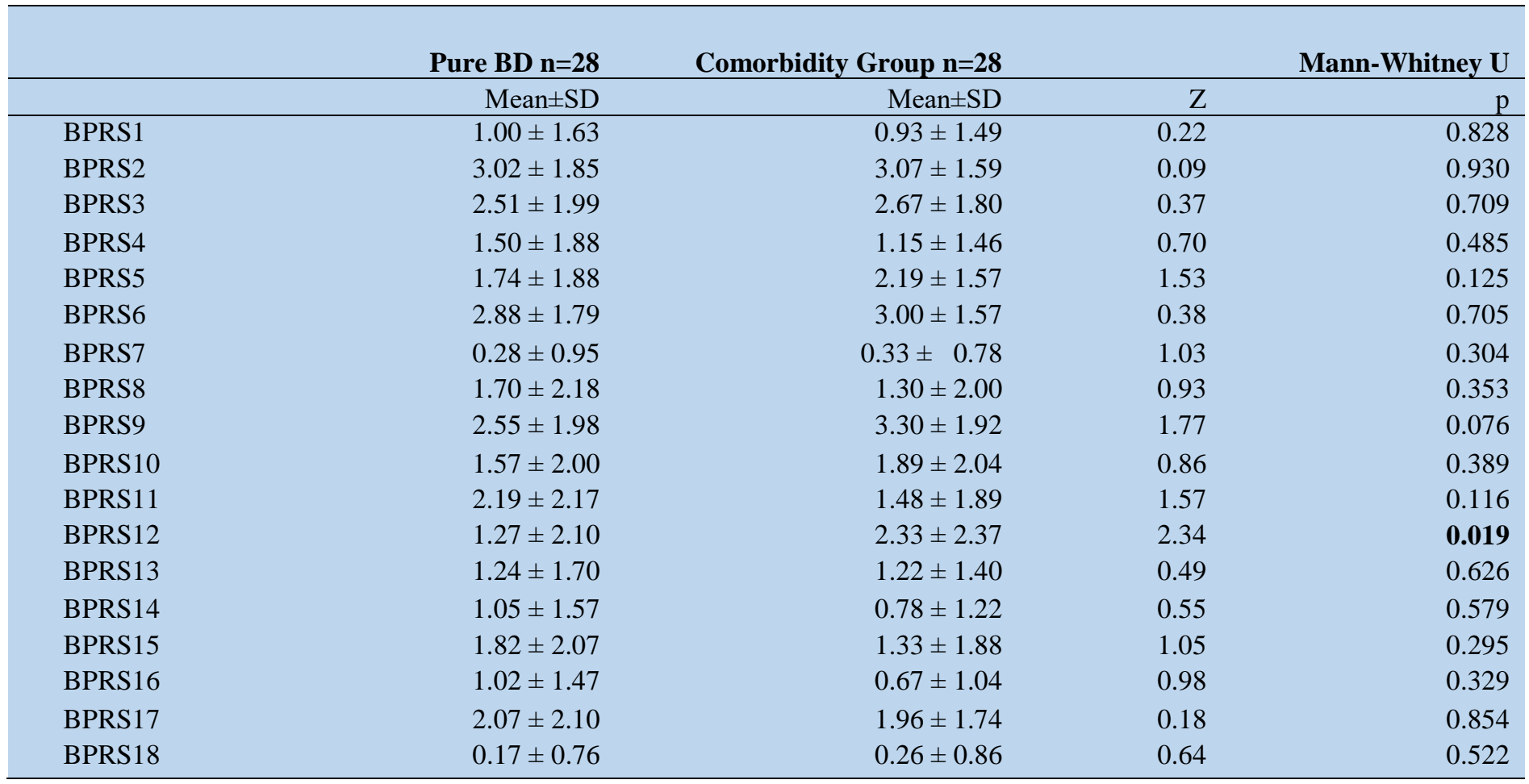

BPRS: Brief Psychotic Rating Scale. BD: Bipolar Disorder *p<0.05 SD: Standard Deviation

Table 4. BPRS item scores of patient groups at discharge

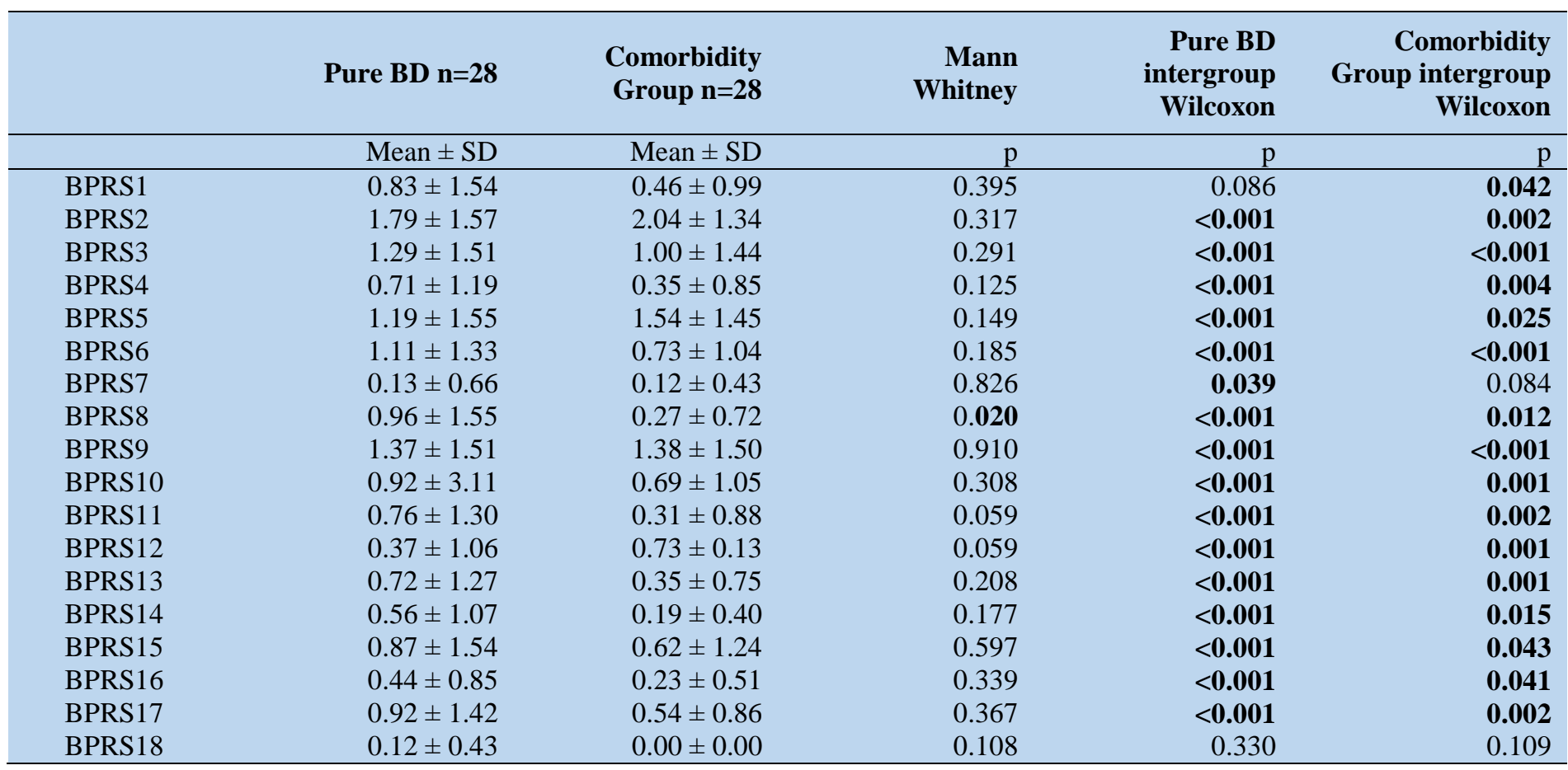

BPRS: Brief Psychotic Rating Scale. BD: Bipolar Disorder *p<0.05 SD: Standard Deviation

Among YMRS scores at admission, both 6th item (velocity and amount of speech) and 11th item (insight) were significantly higher in the pure $\mathrm{BD}$ group compared to comorbidity group $(\mathrm{z}=2.22, \mathrm{p}=0.027 ; \mathrm{z}=2.73, \mathrm{p}=0.006$, respectively) (Table 5). Among YMRS scores at discharge, 6th item score was significantly higher in the pure BD group compared to comorbidity group $(\mathrm{z}=2.36, \mathrm{p}=0.018)$ (Table 6).
In the pure bipolar group, all items were significantly different between the time of admission and the time of discharge. In the comorbidity group, a significant difference was found between the scores at the time of admission and at the time of discharge, except for 1st (expansive mood), 2nd (increased movement and energy), 3rd (sexual interest), 9th (disruptiveaggressive behavior) and 11th (insight) items (Table 5 and 6). 
Table 5. YMRS item scores of patient groups at admission

\begin{tabular}{lrrr} 
& Pure BD n=28 & Comorbidity Group n=28 & Mann-Whitney U \\
\hline & Mean \pm SD & Mean \pm SD & Z \\
\hline YMRS1 & $1.28 \pm 1.29$ & $0.96 \pm 1.10$ & 1.02 \\
YMRS2 & $1.45 \pm 1.45$ & $1.04 \pm 1.37$ & 0.309 \\
YMRS3 & $0.80 \pm 1.04$ & $0.36 \pm 0.64$ & 0.166 \\
YMRS4 & $1.91 \pm 1.16$ & $2.16 \pm 0.85$ & 0.054 \\
YMRS5 & $2.56 \pm 1.90$ & $2.60 \pm 1.47$ & 0.78 \\
YMRS6 & $2.53 \pm 2.40$ & $1.28 \pm 1.51$ & 0.13 \\
YMRS7 & $0.99 \pm 1.04$ & $0.52 \pm 0.65$ & 2.22 \\
YMRS8 & $3.61 \pm 3.43$ & $2.96 \pm 3.66$ & 0.896 \\
YMRS9 & $1.03 \pm 1.74$ & $0.60 \pm 1.04$ & $0.027^{*}$ \\
YMRS10 & $0.78 \pm 0.79$ & $0.72 \pm 0.74$ & 0.050 \\
YMRS11 & $1.03 \pm 1.39$ & $0.24 \pm 0.66$ & 0.321 \\
\hline YMRS: Y & 0.491 & 0.69 \\
\end{tabular}

YMRS: Young Mania Rating Scale. BD: Bipolar Disorder * $p<0.05$ SD: Standard Deviation

Table 6. YMRS item scores of patient groups at discharge

\begin{tabular}{|c|c|c|c|c|c|}
\hline & $\begin{array}{r}\text { Pure BD } \\
n=28\end{array}$ & $\begin{array}{r}\text { Comorbidity Group } \\
n=28\end{array}$ & Mann Whitney & $\begin{array}{r}\text { Pure BD intergroup } \\
\text { Wilcoxon }\end{array}$ & $\begin{array}{l}\text { Comorbidity Group } \\
\text { intergroup Wilcoxon }\end{array}$ \\
\hline & Mean \pm SD & Mean \pm SD & $\mathrm{p}$ & $\mathrm{p}$ & $\mathrm{p}$ \\
\hline YMRS1 & $0.66 \pm 0.80$ & $0.79 \pm 1.02$ & 0.710 & $<0.001 *$ & 0.403 \\
\hline YMRS2 & $0.65 \pm 0.95$ & $0.71 \pm 1.00$ & 0.837 & $<0.001 *$ & 0.107 \\
\hline YMRS3 & $0.46 \pm 0.75$ & $0.21 \pm 0.41$ & 0.182 & $<0.001 *$ & 0.234 \\
\hline YMRS4 & $0.50 \pm 0.87$ & $0.38 \pm 0.58$ & 0.997 & $<0.001 *$ & $<0.001 *$ \\
\hline YMRS7 & $0.40 \pm 0.60$ & $0.13 \pm 0.34$ & 0.035 & $<0.001 *$ & 0.029* \\
\hline YMRS8 & $1.61 \pm 2.31$ & $1.42 \pm 2.10$ & 0.840 & $<0.001 *$ & 0.018* \\
\hline YMRS9 & $0.37 \pm 1.08$ & $0.29 \pm 0.62$ & 0.544 & $<0.001 *$ & 0.253 \\
\hline YMRS10 & $0.42 \pm 0.59$ & $0.33 \pm 0.64$ & 0.360 & $<0.001 *$ & 0.008* \\
\hline YMRS11 & $0.55 \pm 1.04$ & $0.17 \pm 0.38$ & 0.128 & $<0.001 *$ & 0.705 \\
\hline
\end{tabular}

YMRS: Young Mania Rating Scale. BD: Bipolar Disorder *p<0.05 SD: Standard Deviation

\section{DISCUSSION}

Among the participants of the study, $18.7 \%(n=28)$ had a dissociative disorder. In randomly selected psychiatric inpatients, the prevalence of pathological dissociation was reported to range between 5.4 and $12.7 \%(25,26)$. Some North American $(27,28)$ studies and one Turkish study (29) found the incidence rates higher than $10 \%$ for DD. DID was found to be within the range of $0.4-12 \%(25,27)$. In our study, it is thought that elevated rates of dissociative disorder could be related to the performance of the study in the group of BD population. Severe childhood trauma appears to have occurred in about half of patients with bipolar disorder, and may lead to more complex psychopathological manifestations (30). Patients with dissociative disorders frequently report childhood abuse and neglect (31).

In the studies that investigated the incidence of depression in the dissociative disorders, the rates of lifetime depression was observed to be high (31). In the analysis of the National Institute of Mental Health Collaborative Depression Study (CDS) performed at the end of 10 years of follow-up, approximately $10 \%$ of those with MDD developed bipolar disorder (32). In another study, it was determined that, after a mean period of 17.5 years, $12.2 \%$ of the patients diagnosed with depression showed the conversion to bipolar II disorder and $7.5 \%$ showed the conversion to bipolar I disorder (33). It is thought that probably due to the sectional nature of the studies about the depression comorbidities, the cases of bipolarity were overlooked. Similarly, in the studies about DID, DID was commonly misdiagnosed as schizophrenia (34).

The majority of the literature about $\mathrm{BD}$ and dissociative disorder comorbidity mostly comprises of case reports. Among these publications, Coryell reported in a single case report that multiple personality may occur as an epiphenomenon of the affective disorder or of other illnesses (35). Bliss examined the symptom profiles of a cohort of DID patients and found that more than half experienced depressive symptoms, and approximately $38 \%$ of patients displayed signs of mania or hypomania (36). Steingard and Frankel (37) reported a 17-year-old girl presenting with a diagnosis of bipolar affective disorder, rapid cycling type, who in fact was experiencing dissociative episodes manifested as psychotic states. Two patients from India, one being with bipolar 
affective disorder, were reported to have suffered from a dissociative loss of consciousness during their psychotic episodes (38). Giese et al. (39) described three patients with psychotic mood disorders and prominent dissociative symptoms that remitted with successful somatic treatment.

When comorbid and pure BD groups were compared in terms of DES scores, total DES score of the patients included in the comorbidity group was found to be significantly higher. A significant correlation was detected between total DES score and hospital stay. Our results are consistent with the results of the studies performed by Michelson et al. (40) and Rufer et al. (41) showing that the presence of the dissociation decreases the therapeutic response and increases relapse rates. This may suggest that the presence of dissociation may have unfavorable effects on the course of the disease. Childhood abuse and neglect are the risk factors associated with worsening of clinical course in bipolar disorder (42). Childhood abuse was associated with suicidal ideation and suicide attempts in adults with bipolar disorder (43).

Comorbidity group was younger than the pure bipolar group. Few studies found that pathological dissociation seemed to be more frequent in younger individuals $(26,44)$.

HAM-D suicide item was significantly higher in the comorbidity group compared to pure bipolar group comparable to the evaluation at discharge. Presence of a dissociative disorder is strongly associated with all measures of self-harm and suicidality (45). Self-destructive behavior is very common in the cases of DID. While their rate of completed suicide was reported to be $1-2 \%$, the patients with dissociative disorders both attempt suicide and self-mutilate without having suicidal intention much more frequently (45). Of 236 cases, Ross found that 72 percent had attempted suicide and 2.1 percent committed suicide (46). Another study from Turkey found that $37.5 \%$ of the patients had suicidal thoughts upon the diagnosis of either dissociative identity disorder or dissociative disorder not otherwise specified (47).

In the pure bipolar group, HAM-D item scores at admission and at discharge showed significant differences except for 17 th item. In the comorbidity group, scores obtained at admission and at discharge showed significant differences except for 9th (agitation), 11th (somatic anxiety), 15th (hypochondriasis), 16th (weight loss) and 17th (insight about the condition) items. Dissociative psychopathology seems to be an important predictor for poor treatment response and high relapse rates, at least in patients with panic and obsessive-compulsive disorders $(40,41)$. A concurrent dissociative disorder more generally predicted higher psychiatric comorbidity, including somatization disorder, dysthymic disorder, major depression, borderline personality disorder, self-destructive behavior, suicide attempts, and childhood trauma (48).

Among BPRS scores at admission, hallucinatory phenomena item was found to be significantly higher in the comorbidity group compared to pure bipolar group. This is an expected finding in the dissociative disorders. Ross \& Norton (49) reported that the clinical triad of dissociative identity disorders included Schneiderian made-impulses, voices in the head, and suicide attempts. Hallucinatory phenomena are very common in DID. In about $80 \%$ of cases, DID patients experience voices or conversations within the mind (50). Visual hallucinations and illusions are quite common in DID patients. Hypnogogic and hypnopompic imageries are also common (51). Compared to schizophrenia, DID patients are more likely to have voices starting before 18 , hear more than 2 voices, have both child and adult voices and experience tactile and visual hallucinations. Pathological dissociation predicted several aspects of voice hearing and appears an important variable in voice hearing (52).

For BPRS scores at discharge, grandiosity was found to be higher in the pure bipolar group compared to comorbidity group. In the pure bipolar group, BPRS scores at admission and at discharge showed significant difference except for somatic occupations and disorientation. In the comorbidity group, BPRS scores at admission and at discharge showed significant difference except for manierism-posture and disorientation. It is thought that, in the comorbidity group, the failure of significant improvement in the mannerism-posture and disorientation items may be associated with natural signs of the dissociation, such as inner voices, hallucinatory behaviors and depersonalization or derealization.

YMRS scores including velocity and amount of speech and insight items were significantly higher in the pure bipolar group compared to comorbidity group between admission and discharge. Among YMRS scores at discharge, velocity and amount of speech was found to be significantly higher in the in the pure bipolar group compared to comorbidity group. In the pure bipolar group, all items showed significant differences between admission and discharge. In the comorbidity group, significant differences were detected between admission and discharge, except for expansive mood, increased movement and energy, sexual interest, disruptiveaggressive behavior and insight. In the group with dissociation comorbidity, low scores for sexual interest both at admission and at discharge suggest that there was no increase of sexual interest, probably due to eventual previous harassments. In adult DID, sexual dysfunction is usually present (53). Female DID patients often have alters who exhibit a form of secondary lesbianism. They experience difficulties in having normal sexual relations with men because of the past sexual abuses. The alters are therefore sexually attracted to women, but primarily as a way of getting physical intimacy, affection, and warmth. For these alters, sex is a secondary issue in their sexual activity which forms analogy with male heterosexual rape, in which the main issues are power, anger, and revenge rather than sex (46). In the comorbidity group, the stability of expansive mood, increased movement and energy, disruptiveaggressive behavior and insight among YMRS items may be attributable to the presence of high personality disorder comorbidity in the dissociative disorders. Dissociative disorders tend to be closely related to a wide range of personality disorder symptoms $(54,55)$. Coons et al. (56) concluded that DID was a "syndrome" that occurred in people with disturbed personalities, particularly borderline personality disorder, and that both borderline personality disorder and DID were on the same character disorder spectrum, with DID representing its more severe end. They argued that DID arise from a substrate of borderline traits.

Both epidemiological and clinical studies show that dissociative disorders were more common than previously estimated $(7,28,29,57)$, because it is highly likely to misdiagnose dissociative disorders, especially dissociative identity disorder, as another psychiatric disorder. This may result from the facts that these disorders have multiple symptoms and that the symptoms of this condition may overlap with the symptoms of other disorders (58). 
Some limitations need to be mentioned. First limitation of our study was the evaluation of the patients using SCID-II, leading to an inadequate detection of the effects of personality disorder comorbidity. Second limitation of our study was the inability to compare the patients with and without comorbidity by their clinical characteristics due to small number of male patients. Therefore, our data need confirmation in larger samples. Third limitation of the study was childhood trauma was not evaluated.

Conclusion: The administration of the structured clinical interviews in a manner to evaluate dissociative disorders (as SCID-D) may allow determining the dissociative disorder comorbidity more accurately. Thereby, it is important to eliminate the risk for suicide and self-harm and to determine the factors of poor prognosis in advance.

\section{Conflict of interest: None.}

\section{Financial support: None.}

\section{REFERENCES}

1. Kessler RC, Rubinow DR, Holmes C, Abelson JM, Zhao S. The epidemiology of DSM-III-R bipolar disorder I disorder in a general population survey. Psychol Med 1997;27: 1079-89.

2. Akiskal HS, Bourgeois ML, Angst J, Post R, Moller $\mathrm{H}$,Hirschfeld R. Re-evaluating the prevalence of and diagnostic composition within the broad clinical spectrum of bipolar disorders. J Affect Disord 2000; 59(suppl 1): S5-S30.

3. Angst J, Gamma A, Benazzi F, Ajdacic V, Eich D, Rossler W. Toward a re-definition of subthreshold bipolarity: epidemiology and proposed criteria for bipolar-II, minor bipolar disorders and hypomania. J Affect Disord 2003; 73:133-46.

4. McElroy SL. Diagnosing and treating comorbid (complicated) bipolar disorder. J Clin Psychiatry 2004; 65(suppl 15):35-44.

5. Vieta E, Colom F, Corbella B, et al. Clinical correlates of psychiatric comorbidity in bipolar I patients. Bipolar Disord 2001; 3:253-8.

6. Loewenstein RJ. Diagnosis, epidemiology, clinical course, treatment, and cost effectiveness of treatment for dissociative disorders and MPD: report submitted to the Clinton Administration. Dissociation 1994; 7:3-11.

7. Ross CA, Joshi S, Currie R. Dissociative experiences in the general population. American Journal of Psychiatry 1990; 147:1547-52.

8. Gershuny BS, Thayer JF. Relations among psychological trauma, dissociative phenomena, and trauma-related distress: a review and integration. Clin Psychol Rev 1999; 19:631-57.

9. Steiner H, Carrion V, Plattner B et al. Dissociative symptoms in posttraumatic stress disorder: diagnosis and treatment. Child Adolesc Psychiatr Clin N Am 2003; 12:231-49.

10. Schäfer I, Ross CA, Read J. Childhood trauma in psychotic and dissociative disorders. In Moskowitz A, Schäfer I, Dorahy MJ, (eds). Psychosis, trauma and dissociation. Emerging perspectives on severe psychopathology. Wiley-Blackwell; 2008.
11. Yargic LI, Sar V, Tutkun H, Alyanak B. Comparison of dissociative identity disorder with other diagnostic groups using a structured interview in Turkey. Compr Psychiatry 1998; 39:345-51.

12. Lipsanen T, Korkeila J, Peltola P, Jarvinen J, Langen K, Lauerma H. Dissociative disorders among psychiatric patients comparison with a nonclinical sample. Eur Psychiatry 2004; 19:53-5.

13. First MB, Spitzer RL, Gibbon M, Williams JBW. Structured Clinical Interview for DSM-IV Axis I Disorders (SCID-I), Clinical Version. Washington D.C, American Psychiatric Press; 1997.

14. Çorapçıŏlu A, Aydemir Ö, Yıldız M ve ark. DSM-IV Eksen I Bozuklukları (SCID-I) İçin Yapılandırılmış Klinik Görüşme, Klinik Versiyon. Ankara, Hekimler Yayın Birliği; 1999.

15. Hamilton M. A Rating Scale For Depression By Max Hamilton. J Neurol Neurosurg Psychiat 1960; 23: 56.

16. Akdemir A. Hamilton depresyon derecelendirme ölçeğinin geçerliği-güvenirliği ve klinikte kullanımı. 3P Dergisi 1996; 4: 251-9.

17. Young RC, Biggs JT, Ziegler et al. A rating scale for mania: reliability, validity and sensitivity. Br J Psychiatry 1978; 133: 429-35.

18. Karadağ F. Young mani değerlendirme ölçeğinin Türkçe çevirisinin güvenirlik ve geçerlik çalışması. Turk Psikiyatri Derg 2002; 13: 107-14.

19. Overall JE, Gorham DR. The brief psychiatric rating scale. Psychol Reports 1962;10: 799-812.

20. Soykan C. Institutional differences and case typicality as related to diagnosis system severity, prognosis and treatment. Master tezi, Ortadoğu Teknik Üniversitesi, Ankara; 1982.

21. Carlson EB. Putnam FW. Ross CA, et al. Validity of the Dissociative Experiences Scale in screening for multiple personality disorder: a multicenter study. Am J Psychiatry 1993:150:1030-6.

22. Yargıç Lİ, Tutkun H, Şar V. The reliability and validity of the Turkish version of the Dissociative Experiences Scale. Dissociation 1995; 8:10-3.

23. Steinberg M: Structured Clinical Interview for DSM-IV Dissociative Disorders (SCID-D), Revised. Washington, DC, American Psychiatric Press; 1994.

24. Şar V, Tutkun H, Yargiç Lİ ve ark: DSM-IV Dissosiyatif Bozukluklar İçin Yapılandırılmış Görüşme Çizelgesi (SCID-D) Türkçe Versiyon. İstanbul Tıp Fakültesi Psikiyatri Anabilim Dalı Klinik Psikoterapi Birimi, İstanbul; 1996.

25. Modestin J, Erni T. Testing the dissociative taxon. Psychiatry Res 2004;126:77-82.

26. Spitzer C, Barnow S, Grabe HJ et al. Frequency, clinical and demographic correlates of pathological dissociation in Europe. J Trauma Dissociation 2006; 7:51-62.

27. Latz TT, Kramer SI, Hughes DL. Multiple personality disorder among female inpatients in a state hospital. Am J Psychiatr 1995; 152:1343-8.

28. Saxe GN, van der Kolk BA, Berkowitz R, et al. Dissociative disorders in psychiatric inpatients. Am J Psychiatr 1993; 150:1037-42.

29. Tutkun H, Sar V, Yargic LI, Ozpulat T, Yanik M, Kiziltan E. Frequency of dissociative disorders among psychiatric inpatients in a Turkish University Clinic. Am J Psychiatr 1998; 155:800-5. 
30. Garno JL, Goldberg JF, Ramirez PM, Ritzler BA. Impact of childhood abuse on the clinical course of bipolar disorder. Br J Psychiatry 2005; 186:121-5.

31. Sar V, Akyuz G, Dogan O. Prevalence of dissociative disorders among women in the general population. Psychiatr Res 2007; 149:169-76.

32. Coryell W, Endicott J, Maser JD, Keller MB, Leon AC, Akiskal HS. Long-term stability of polarity distinctions in the affective disorders. Am J Psychiatry 1995; 152(3):385-90.

33. Fiedorowicz JG, Endicott J, Leon AC, Solomon DA, Keller MB, Coryell WH. Subthreshold hypomanic symptoms in progression from unipolar major depression to bipolar disorder. Am J Psychiatry 2011;168(1):40-8.

34. Ross CA, Norton GR. Multiple personality patients with a past diagnosis of schizophrenia. Dissociation 1988; 1(2):39-42.

35. Coryell W. Single case study. Multiple personality and primary affective disorder. J Nerv Ment Dis 1983; 171(6):388-90.

36. Bliss EL. A symptom profile of patients with multiple personalities, including MMPI results. J Nerv Ment Dis 1984;172:197-202.

37. Steingard S, Frankel FH. Dissociation and psychotic symptoms. Am J Psychiatry 1985; 142(8): 953.

38. Gupta R, Chawla LS. Dissociation in endogenous psychosis. Am J Psychiatry 1991; 148(3):395-6.

39. Giese AA, Thomas MR, Dubovsky SL. Dissociative symptoms in psychotic mood disorders: an example of symptom nonspecificity. Psychiatry 1997; 60:60-6.

40. Michelson L, June K, Vives A, et al. The role of trauma and dissociation in cognitive-behavioral psychotherapy outcome and maintenance for panic disorder with agoraphobia. Behav Res Ther 1998; 36:1011-50.

41. Rufer M, Held D, Cremer J, et al. Dissociation as a predictor of cognitive behavior therapy outcome in patients with obsessive compulsive disorder. Psychother Psychosom 2006; 75:40-6.

42. Daruy-Filho L, Brietzke E, Lafer B, Grassi-Oliveira R. Childhood maltreatment and clinical outcomes of bipolar disorder. Acta Psychiatr Scand 2011

43. McIntyre RS, Soczynska JK, Mancini D, et al. The relationship between childhood abuse and suicidality in adult bipolar disorder. Violence Vict 2008; 23(3):361-72.

44. Seedat S, Stein MB, Forde DR. Prevalence of dissociative experiences in a community sample: relationship to gender, ethnicity, and substance use. J Nerv Ment Dis 2003; 191:115-20.

45. Foote B, Smolin Y, Neft DI, Lipschitz D. Dissociative disorders and suicidality in psychiatric outpatients. J Nerv Ment Dis 2008; 196(1):29-36.

46. Ross AC. Multiple personality disorder. Diagnosis, clinical features, and treatment. John Wiley \& Sons, NewYork, 1989.

47. Oztürk E, Sar V. Somatization as a predictor of suicidal ideation in dissociative disorders. Psychiatry Clin Neurosci 2008; 62(6):662-8.

48. Sar V, Akyuz G, Kundakci T, et al. Childhood trauma, dissociation,and psychiatric comorbidity in patients with conversion disorder. Am J Psychiatry 2004; 162:271-6.

49. Ross CA, Norton GR. Differences between men and women with multiple personality disorder. Hosp Community Psychiatry 1989; 40(2):186-8.
50. Kluft RP. The dissociative disordes. In Talbot JA, HalesRE, Yudofsky SC (eds). The American Psychiatric Press Textbook of Psychiatry. Washington DC, American Psychiatric Press; 1988.

51. Putnam FW. Diagnosis and treatment of multiple personality disorder. NewYork, Guilford; 1989.

52. Ashton AK. Structured sexual therapy with severely dissociative patients. J Sex Marital Ther 1995; 21(4):27681.

53. Coons PM, Milstein V. psychosexual disturbances in ple personality: characteristics, etiology, and treatment. J Clin Psychiatry 1986; 47:106-10.

54. Allen JG, Coyne L, Console DA. Dissociative detachment relates to psychotic symptoms and personality decompensation. Comprehensive Psychiatry 1997; 38:327-34.

55. Sar V, Kundakci T, Kiziltan E, et al. The Axis-I dissociative disorder comorbidity of borderline personality disorder among psychiatric outpatients. J Trauma Dissociation 2003; 4:119-36.

56. Coons PM, Sterne AL. Initial and follow-up psychological testing on a group of patients with multiple personality disorder. Psychol Rep 1986; 58:43-9.

57. Akyüz G, Doğan $O$, Şar V, et al. Frequency of dissociative identity disorder in the general population in Turkey. Compr Psychiatry 1999; 40:20-4.

58. American Psychiatric Association: Diagnostic and Statistical Manual of Mental Disorders. 4th ed. Washington D.C., American Psychiatric Association; 1994. 